\title{
CHLORIDE, BROMIDE, SODIUM, AND SUCROSE SPACES IN MAN 1
}

\author{
By JAMES L. GAMBLE, JR., JAMES S. ROBERTSON, CHARLES A. HANNIGAN, \\ EITARLES G. FOSTER, AND LEE E. FARR
}

(From the Medical Department, Brookhaven National Laboratory, Upton, L. I., N. Y.)

(Submitted for publication January 10, 1953; accepted, February 27, 1953)

\section{INTRODUCTION}

Present methods for measuring the volume of the extracellular fluid have well recognized limitations. There is no known substance that is distributed uniformly throughout the blood plasma, interstitial fluid, gastrointestinal juices and the cerebrospinal fluid, and which also maintains an exclusively extracellular position. Further, it is now realized that when using the dilution methods prolonged time intervals must be allowed before equilibrium can be assumed to be complete ; and increased time necessarily magnifies such unavoidable errors as those caused by the metabolism of the agent or by its loss through the skin. In spite of these limitations, serial determinations of the volumes of distribution of certain of these agents are useful to study variations of the volume of extracellular fluid and to indicate changing distributions, between extra- and intracellular compartments, of substances studied simultaneously. In these distribution studies, when using the electrolytes, it is important that the extracellular fluid be considered to include all of the non-intracellular compartments.

In this report, the volume of distribution of chloride is emphasized. In recent years the distribution of chloride has been the most frequently used index of the extracellular fluid in both balance studies and tissue analyses. In addition, the measurement of the dilution $n_{i}$ of radioactive chloride in the body is a simple and accurate procedure, and either $\mathrm{Cl}^{38}$ or $\mathrm{Cl}^{38}$ may be used simultaneously. with any one of many other radioactive isotopes and the individual activities easily distinguished. Experiments in which two isotopes are used simultaneously provide a more dependable and accurate comparison of the separate volumes of distribution than can be obtained when the two determinations must be made at different times. In this study, direct comparisons were made between the radioac-

1 Research carried out under the auspices of the U. S. A.E.C. tive chloride space and the volumes of distribution of bromide, sodium and sucrose in an effort to increase our understanding of the relative significance of these measurements as parameters of the extracellular fluid. Separate determinations of the dilution volumes of these agents have been made previously. The radioactive chloride dilution has been measured by Moore (1) and by Ray, Burch, and Threefoot (2); radioactive sodium by Forbes and Perley (3) ; stable bromide by Brodie, Brand and Leshin (4) and by Dunning, Steele and Berger (5); and sucrose by Deane, Schreiner and Robertson (6). Deane and Smith have simultaneously determined the volumes of distribution of sucrose and sodium (7) and of sucrose and bromide (8).

\section{METHODS}

A previous report from this laboratory (9) has described the methods used in this study to prepare, inject and count $\mathrm{Cl}^{2 \mathrm{a}}, \mathrm{Br}^{\mathrm{en}}$, and $\mathrm{Na}^{2 \mathrm{a}}$; to count the individual activities when $\mathrm{Cl}^{\text {so }}$ is used in combination with either $\mathrm{Na}^{2 \mathrm{~s}}$ or $\mathrm{Br}^{28}$; and to make corrections for the Donnan equilibrium and for the volume displacement of the plasma proteins. When the volumes of distribution of $\mathrm{Na}^{24}$ and of $\mathrm{Cl}^{\mathrm{zs}}$ were to be determined simultaneously, a dry salt mixture was prepared which contained $6 \mathrm{mgm}$. of ammonium chloride per kilogram of the subject's weight and $0.3 \mathrm{mgm}$. of sodium chloride per kilogram of the subject's weight. The salts were irradiated in the Brookhaven reactor (flux $5 \times 10^{12}$ neutrons per $\mathrm{cm}^{2}$-sec.) for 10 minutes in Lucite cups. The temperature of $175^{\circ} \mathrm{C}$. and the intense radiation of the interior of the reactor provided sterilization. The radioactive salts were dissolved in sterile distilled water, and the preparation was then ready for injection without further processing. An aliquot was diluted in saline to serve as the measure of the injected activities. Blood samples were drawn at one and at two and one-half hours. The separate volumes of distributions were calculated from two counting series as described. When $\mathrm{Br}^{23}$ and $\mathrm{Cl}^{20}$ were used together, the $\mathrm{Br}^{\mathrm{az}}$ was prepared and standardized separately.

In experiments on normal subjects the accepted tolerance radiation dose rate of 300 millirep per week should not be exceeded. A total dose of 300 millirep will be delivered in an experiment in which the isotopes or combinations of isotopes are used in the following initial 
TABLE I

Simultaneous measurements of the volumes of distribution of radioactive chloride, radioactive sodium, stable bromide, and sucrose.

\begin{tabular}{|c|c|c|c|c|c|c|c|c|c|}
\hline \multirow{2}{*}{$\begin{array}{c}\text { Patient } \\
\text { and } \\
\text { Diagnosis }\end{array}$} & \multirow[b]{2}{*}{ Ht. } & \multirow[b]{2}{*}{ Wt. } & \multirow{2}{*}{$\begin{array}{c}\text { Serum } \\
\mathrm{Na}\end{array}$} & \multirow{2}{*}{$\begin{array}{c}\text { Serum } \\
\mathrm{Cl}\end{array}$} & \multirow[b]{2}{*}{ Agent } & \multicolumn{4}{|c|}{ Volume of Distribution (liters) } \\
\hline & & & & & & $1 \mathrm{hr}$. & $2.5 \mathrm{hr}$. & $4 \mathrm{hr}$. & $21 \mathrm{hr}$. \\
\hline $\begin{array}{c}\text { E. L. } \\
\text { Thyroid } \\
\text { Malignancy }\end{array}$ & cm. & $\begin{array}{l}\text { kg. } \\
68.1\end{array}$ & $\begin{array}{c}\mathrm{mE} . / 1 \\
143\end{array}$ & $\begin{array}{c}\mathrm{mE} . / 1 . \\
108\end{array}$ & $\begin{array}{l}\mathrm{Cl}^{38} \\
\text { Na } 24 \\
\text { Stable } \\
\text { Bromide } \\
\text { Sucrose }\end{array}$ & $\begin{array}{l}19.7 \\
20.3 \\
\\
20.7 \\
14.8\end{array}$ & $\begin{array}{l}19.6 \\
21.5 \\
21.1 \\
15.1\end{array}$ & 15.4 & $\begin{array}{l}23.7 \\
21.2\end{array}$ \\
\hline $\begin{array}{c}\text { D. Y. } \\
\text { Thyroid } \\
\text { Malignancy }\end{array}$ & 147 & 41 & 139 & 104 & $\begin{array}{l}\mathrm{Cl}^{38} \\
\text { Na24 } \\
\text { Stable } \\
\text { Bromide } \\
\text { Sucrose }\end{array}$ & $\begin{array}{r}9.1 \\
9.7 \\
10.0 \\
6.4\end{array}$ & $\begin{array}{r}10.2 \\
11.0 \\
10.7 \\
8.7\end{array}$ & 9.3 & $\begin{array}{l}12.4 \\
11.4\end{array}$ \\
\hline $\begin{array}{c}\text { J. P. } \\
\text { Thyroid } \\
\text { Malignancy }\end{array}$ & 155 & 54.8 & 142 & 105 & $\begin{array}{l}\mathrm{Cl}^{38} \\
\text { Na24 } \\
\text { Stable } \\
\text { Bromide } \\
\text { Sucrose }\end{array}$ & $\begin{array}{r}12.2 \\
12.7 \\
12.8 \\
8.4\end{array}$ & $\begin{array}{r}11.9 \\
13.2 \\
13.4 \\
8.9\end{array}$ & 9.6 & $\begin{array}{l}15.1 \\
13.6\end{array}$ \\
\hline $\begin{array}{l}\text { P. R. } \\
\text { Hyper- } \\
\text { tension }\end{array}$ & 173 & 78.2 & 142 & 105 & $\begin{array}{l}\mathrm{Cl}^{38} \\
\text { Na24 } \\
\text { Stable } \\
\text { Bromide } \\
\text { Sucrose }\end{array}$ & $\begin{array}{l}21.4 \\
21.8 \\
22.7 \\
13.6\end{array}$ & $\begin{array}{l}23.0 \\
23.5 \\
24.7 \\
15.0\end{array}$ & 16.2 & $\begin{array}{l}26.2 \\
25.6\end{array}$ \\
\hline $\begin{array}{l}\text { A. H. } \\
\text { Brain } \\
\text { Tumor }\end{array}$ & & 48.0 & 142 & 102 & $\begin{array}{l}\mathrm{Cl}^{38} \\
\mathrm{Na}^{24} \\
\text { Stable } \\
\text { Bromide } \\
\text { Sucrose }\end{array}$ & $\begin{array}{r}13.1 \\
13.3 \\
14.4 \\
9.3\end{array}$ & $\begin{array}{l}13.4 \\
14.1 \\
13.8 \\
10.1\end{array}$ & 10.4 & $\begin{array}{l}16.1 \\
14.1\end{array}$ \\
\hline
\end{tabular}

concentrations :

$2.7 \mu c$. per $\mathrm{Kg}$. of $\mathrm{Na}^{24}$;

$68.2 \mu \mathrm{c}$. per $\mathrm{Kg}$. of $\mathrm{Cl}^{28}$;

$1.7 \mu \mathrm{c}$. per $\mathrm{Kg}$. of $\mathrm{Br}^{82}$;

$0.5 \mu c$. per $\mathrm{Kg}$. of $\mathrm{Na}^{24}$ with $56 \mu \mathrm{c}$. per $\mathrm{Kg}$. of $\mathrm{Cl}^{\mathrm{s}}$;

$0.4 \mu$ c. per $\mathrm{Kg}$. of $\mathrm{Br}^{20}$ with $52 \mu \mathrm{c}$. per $\mathrm{Kg}$. of $\mathrm{Cl}^{28}$.

In the calculations for the above values the definition of the rep as the absorption of 93 ergs per gram of tissue was used. In this study $5 \mathrm{ml}$. portions of plasma were counted in a multiple anode gamma sensitive counter, ${ }^{2}$ and the counting was done before three hours had elapsed from the time of injection. Without exceeding 300 millirep per week, sufficiently high counting rates were obtained so that the maximum standard error of any counting period was less than 2 per cent.

The sucrose spaces were determined using the method described by Deane, Schreiner and Robertson (6). No priming injection was given. The sucrose infusion was started 15 minutes after the solution of $\mathrm{Na}^{24}, \mathrm{Cl}^{28}$ and stable bromide had been injected. As all the agents were determined from the same blood samples, the sucrose was analyzed in samples obtained 15 minutes earlier, in relation to the start of the infusion, than is indicated in Table

2 Donated by the Texas Oil Co. (H18-20 TR).
I. Separate volumes of distribution were calculated from the data obtained from each blood sample. The sucrose was hydrolyzed and the resulting levulose measured as in Schreiner's method for inulin (10). Stable bromide determinations were made using the method of Brodie and Friedman (11). The serum sodium concentrations were measured by flame photometry, serum chloride concentrations by the method of Van Slyke and Hiller (12), and serum proteins by the copper sulphate technique (13). For the purpose of the Donnan equilibrium corrections, the plasma volume was assumed to be 5 per cent of the ideal weight. All volumes of distribution calculations were corrected for the amount of the agent excreted in the urine.

\section{RESULTS}

The results of the simultaneous determinations of the volumes of distribution of $\mathrm{Cl}^{38}, \mathrm{Na}^{24}$, sucrose and stable bromide are tabulated in Table I. The values from the first patient are plotted in Figure 1. It is apparent from examination of Table I that equilibrium of sucrose and of $\mathrm{Cl}^{\text {s8 }}$ has not been conclusively established. Unfortunately, data that could be used to extend these curves are not read- 
ily obtainable. Activities of $\mathrm{Cl}^{38}$ that will give the patient less than 0.3 rep per experiment cannot be followed for appreciably longer periods of time with presently available counting equipment. With the Deane sucrose method, accuracy of the volume of distribution measurement becomes progressively more difficult to obtain when, after three to five hours, the amount of sucrose appearing in the urine exceeds half of the amount infused (6). Hence the method is not adaptable to prolonged experiments. For the purposes of the following summary, the two and one-fourth hour and three and three-fourths hour values were averaged to give the "three hour" sucrose space.

The results of previous studies $(3,4)$ indicate that the $\mathrm{Na}^{24}$ and bromide spaces will have expanded to within a few per cent of the maximum or equilibrium values by 21 hours.

These dilution measurements (Table I) were performed on five chronically ill, non-edematous patients. Only patient A. H. was bed-ridden. P. R. was the only male. Converting these volumes to per cent body weight yields the following values :

$\mathrm{Cl}^{38}$ at $21 / 2$ hours-22 to 29 per cent (mean 26.5 per cent), Stable bromide at 21 hours-25 to 33 per cent (mean 29.1 per cent),

$\mathrm{Na}^{24}$ at 21 hours-28 to 35 per cent (mean 31.9 per cent), Sucrose at 3 hours-17 to 22 per cent (mean 20.5 per cent).

Although these were hospital patients, the results are in accord with the data of other workers who used normal subjects (2-6). Further, the "three hour" sucrose spaces of this study varied between 61 and 79 per cent (mean 70.5 per cent) of the 21 hour bromide space and between 59 and 73 per cent (mean 64.3 per cent) of the 21 hour sodium space. These values are in agreement with those of Deane $(7,8)$.

In Table II are presented the results of 10 double tracer experiments using $\mathrm{Cl}^{38}$ and $\mathrm{Br}^{82}$. Patient H. B. was edematous, patient J. T. had advanced hydrocephalus, and patient P. P. was bed-ridden. The other six were ambulatory. Patients A. J. and J. P. were relatively obese. All but P. P. were females. The $\mathrm{Br}^{82}$ spaces in this series are larger than the $\mathrm{Cl}^{38}$ spaces by an average of only 2.4 per cent. This close correlation was predicted by earlier workers following the observation that the distribution of bromide is closely proportional to that of chloride in animals $(14,15)$. The values

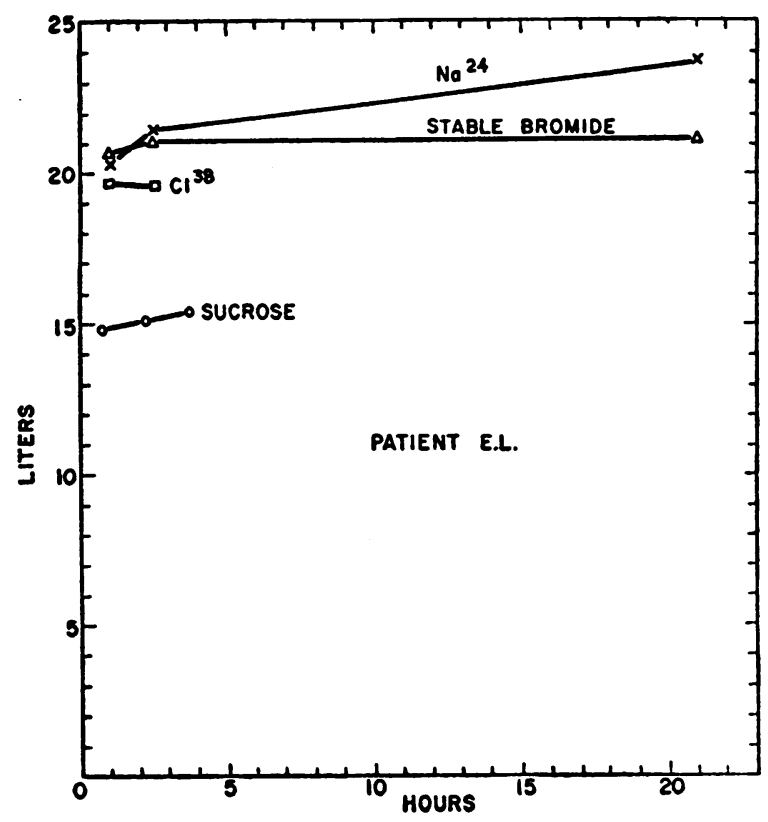

Fig. 1. Simultaneous Determinations of the Volumes of Distribution of $\mathrm{CL}^{28}$, Sucrose, $\mathrm{NA}^{24}$, AND Stable Bromide

of the distribution of stable bromide (Table I) are larger than those of $\mathrm{Cl}^{38}$ by an average of 7 per cent.

The chloride space, when calculated as per cent body weight, was relatively high in the patient with edema ; and, as would be predicted from bromide space measurements (5), relatively low in the more obese subjects.

During the course of these experiments, samples of urine, packed red cells (centrifuged at 2,000 $\mathrm{g}$ for 15 minutes), pleural fluid, gastrointestinal juices and cerebrospinal (ventricular) fluid were counted for both $\mathrm{Cl}^{38}$ and $\mathrm{Br}^{82}$ in the same manner as were the plasma samples. The results are presented in Table III. Despite the close similarity in the over-all dilution values of these two isotopes, there are striking differences in the proportions of the serum concentrations that appear in these samples. The distribution of the two ions relative to each other is described in the sixth column (Table III). These figures were obtained by dividing the sample: serum ratio of the $\mathrm{Br}^{82}$ concentrations by this same ratio for the $\mathrm{Cl}^{38}$ concentrations. The ratios were determined from samples taken at the same time after injection.

In additional measurements (not tabulated in 
TABLE 4

Simultaneous Determinations of the Volumes of Distribution of. $\mathrm{BR}^{82}$ and $C L^{38}$ in Brookhaven Patients

\begin{tabular}{|c|c|c|c|c|c|c|c|c|c|}
\hline \multirow{2}{*}{$\begin{array}{l}\text { Patient } \\
\text { and } \\
\text { Diagnosis }\end{array}$} & \multirow[b]{2}{*}{ Ht. } & \multirow[b]{2}{*}{ wt. } & \multirow[b]{2}{*}{$\begin{array}{l}\text { Serum } \\
\text { Chloride }\end{array}$} & \multirow[b]{2}{*}{ Agent } & \multicolumn{4}{|c|}{ Volume of Distribution } & \multirow{2}{*}{$\begin{array}{c}3 \mathrm{hr} \mathrm{Cl} \mathrm{Cl}^{38} \\
\text { space }\end{array}$} \\
\hline & & & & & \multicolumn{2}{|c|}{1 hour } & \multicolumn{2}{|c|}{2.5 hours } & \\
\hline & $\mathrm{cm}$. & kg. & $\mathrm{ms} . / 1$ & & Liters & Ratio & Liters & Ratio & \% body wt. \\
\hline $\begin{array}{c}\text { H.B. } \\
\text { Leukemia }\end{array}$ & 160 & 47.3 & 100.3 & $\begin{array}{l}\text { Br82 } \\
\text { C138 }\end{array}$ & $\begin{array}{l}20.6 \\
20.3\end{array}$ & 1.01 & $\begin{array}{l}22.1 \\
22.0\end{array}$ & 1.00 & 46.4 \\
\hline $\begin{array}{l}\text { H.F. } \\
\text { Polycythemia }\end{array}$ & 179 & 83.9 & 106.2 & $\begin{array}{l}\text { Br } 82 \\
\text { Cl } 38\end{array}$ & $\begin{array}{l}23.6 \\
23.6\end{array}$ & 1.00 & $\begin{array}{l}23.9 \\
23.4\end{array}$ & 1.02 & 27.9 \\
\hline $\begin{array}{c}\text { A.J. } \\
\text { Ovarian } \\
\text { Malignancy }\end{array}$ & 152 & 67.8 & 105.0 & $\begin{array}{l}\text { Br82 } \\
\text { Cl } 38\end{array}$ & $\begin{array}{l}15.2 \\
14.1\end{array}$ & 1.08 & $\begin{array}{l}15.6 \\
14.6\end{array}$ & 1.07 & 21.5 \\
\hline $\begin{array}{l}\text { P.P. } \\
\text { Brain Tumor }\end{array}$ & 190 & 68.0 & 101.5 & $\begin{array}{l}\mathrm{Br} 82 \\
\mathrm{Cl} 38\end{array}$ & $\begin{array}{l}18.4 \\
18.0\end{array}$ & 1.02 & $\begin{array}{l}19.9 \\
19.4\end{array}$ & 1.03 & 28.5 \\
\hline $\begin{array}{c}\text { P.P. } \\
\text { Brain Tumor }\end{array}$ & 190 & & 97.0 & $\begin{array}{l}\mathrm{Br} 82 \\
\mathrm{Cl} 38\end{array}$ & $\begin{array}{l}16.9 \\
17.3\end{array}$ & 0.98 & $\begin{array}{l}17.3 \\
17.1\end{array}$ & 1.01 & \\
\hline $\begin{array}{c}\text { J.P. } \\
\text { Thyroid } \\
\text { Malignancy }\end{array}$ & 155 & 51.0 & 110.9 & $\begin{array}{l}\mathrm{Br} 82 \\
\mathrm{Cl} 38\end{array}$ & $\begin{array}{l}12.0 \\
11.2\end{array}$ & 1.07 & $\begin{array}{l}12.4 \\
12.0\end{array}$ & 1.03 & 23.4 \\
\hline $\begin{array}{c}\text { A.S. } \\
\text { Uterine } \\
\text { Malignancy }\end{array}$ & 156 & 53.0 & 93.0 & $\begin{array}{l}\mathrm{Br} 82 \\
\mathrm{Cl} 38\end{array}$ & $\begin{array}{l}14.4 \\
13.6\end{array}$ & 1.06 & $\begin{array}{l}15.0 \\
14.6\end{array}$ & 1.03 & 27.5 \\
\hline $\begin{array}{l}\text { J.T. } \\
\text { Hydrocephalus }\end{array}$ & & 4.7 & & $\begin{array}{l}\mathrm{Br}^{82} \\
\mathrm{Cl} 38\end{array}$ & $\begin{array}{l}1.4 \\
1.4\end{array}$ & 1.00 & $\begin{array}{l}1.5 \\
1.4\end{array}$ & 1.01 & \\
\hline $\begin{array}{c}\text { A.D. } \\
\text { Breast } \\
\text { Malignancy }\end{array}$ & 160 & 50.6 & 104.0 & $\begin{array}{l}\mathrm{Br} 82 \\
\mathrm{Cl} 38\end{array}$ & $\begin{array}{l}11.8 \\
11.4\end{array}$ & 1.04 & $\begin{array}{l}13.1 \\
12.8\end{array}$ & 1.02 & 25.3 \\
\hline $\begin{array}{l}\text { C.w: } \\
\text { Thyroid } \\
\text { Malignancy }\end{array}$ & 147 & 63.2 & 94.3 & $\begin{array}{l}\mathrm{Br} 82 \\
\mathrm{Cl} 38\end{array}$ & $\begin{array}{l}15.8 \\
16.1\end{array}$ & 0.98 & $\begin{array}{l}17.0 \\
16.7\end{array}$ & 1.02 & 26.3 \\
\hline
\end{tabular}

Table III), saliva samples were studied 24 hours after the injection of $\mathrm{Br}^{82}$. In two of the patients, A. D. and C. W., the saliva: serum ratio for $\mathrm{Br}^{82}$ was greater than this ratio for naturally occurring stable chloride by factors of 2.3 and 3.0 , respectively.

\section{DISCUSSION}

The $\mathrm{Br}^{82}$ and $\mathrm{Cl}^{38}$ concentrations in the various fluid samples listed in Table III are included here as an evaluation of the use of bromide as an indicator of the chloride space. Although bromide and chloride are distributed in most tissues in proportion to their serum concentrations $(14,15)$, they are not handled "indifferently" by certain of the membranes equipped with active transport systems. The kidney and the choroid plexus apparently show a preference for transporting the chloride ion from the blood stream while the salivary and gastric glands excrete the bromide ion in relatively higher concentrations.

Previous observations comparing the concentrations of bromide and chloride in the blood serum with those found in urine $(16,17)$, red cells $(14$, $17-19)$, transudates $(4,14)$ and saliva $(17)$ are in accord with the results of this report. The relatively high concentrations of bromide in the gastric juice observed in this study, however, were not found by Mason (17) who studied patients with high levels of serum bromide. In this respect it is interesting to note that data, using both stable bromide (20) and stable iodide (21), indicate higher concentration ratios (gastric juice: serum) when the serum concentrations are lower. In the experiments of this study, the amount of carrier for the radioactive bromide was less than $0.1 \mathrm{mgm}$. 
TABLE III

\begin{tabular}{|c|c|c|c|c|c|c|}
\hline Sample & Patient & $\begin{array}{l}\text { Time after } \\
\text { injection }\end{array}$ & $\frac{\mathrm{Br}^{82} \text { conc. sample }}{\text { Br } 82 \text { conc. plasma }}$ & $\frac{\mathrm{Cl}^{38} \text { conc. sample }}{\mathrm{Cl}^{38} \text { conc. plasma }}$ & $\begin{array}{c}\text { Ratio } \\
\text { A/B }\end{array}$ & $\begin{array}{l}\text { Maximum standard } \\
\text { error of the } \\
\text { counting rate }\end{array}$ \\
\hline Urine & $\begin{array}{l}\text { Average } \\
\text { of six }\end{array}$ & $\begin{array}{l}3 \mathrm{hr} \text {. } \\
\text { collection }\end{array}$ & 0.66 & 0.87 & 0.76 & $\begin{array}{c}\text { per cent } \\
2.6\end{array}$ \\
\hline $\begin{array}{l}\text { Packed } \\
\text { red cells }\end{array}$ & $\begin{array}{l}\text { Average } \\
\text { of three } \\
\text { (HB,HF,JP) }\end{array}$ & $\begin{array}{l}1 \mathrm{hr} . \\
3 \mathrm{hrs} .\end{array}$ & $\begin{array}{l}0.54 \\
0.55\end{array}$ & $\begin{array}{l}0.49 \\
0.49\end{array}$ & $\begin{array}{l}1.10 \\
1.12\end{array}$ & 3.0 \\
\hline $\begin{array}{l}\text { Pleural } \\
\text { fluid }\end{array}$ & $\begin{array}{l}\text { Average } \\
\text { of two } \\
\text { (AD, CW) }\end{array}$ & $3 \mathrm{hrs}$. & 0.48 & 0.48 & 1.00 & 2.4 \\
\hline $\begin{array}{l}\text { Gastric } \\
\text { juice }\end{array}$ & PP & $\begin{array}{l}1 \mathrm{hr} . \\
2 \mathrm{hrs} .\end{array}$ & $\begin{array}{l}3.1 \\
4.7\end{array}$ & $\begin{array}{l}0.97 \\
1.4\end{array}$ & $\begin{array}{l}3.2 \\
3.4\end{array}$ & 2.6 \\
\hline $\begin{array}{l}\text { Gastric } \\
\text { juice }\end{array}$ & PP & $\begin{array}{l}5 \text { min. } \\
10 \text { min. } \\
20 \text { min. } \\
40 \text { min. }\end{array}$ & $\begin{array}{l}1.0 \\
1.6 \\
3.3 \\
6.1\end{array}$ & $\begin{array}{l}0.35 \\
0.40 \\
0.84 \\
1.40\end{array}$ & $\begin{array}{l}2.9 \\
4.0 \\
3.9 \\
4.4\end{array}$ & 4.4 \\
\hline $\begin{array}{l}\text { lleostromy } \\
\text { drainage }\end{array}$ & AS & $\begin{array}{l}1.5 \mathrm{hrs} . \\
3 \mathrm{hrs} .\end{array}$ & $\begin{array}{l}0.69 \\
0.78\end{array}$ & $\begin{array}{l}0.81 \\
0.80\end{array}$ & $\begin{array}{l}0.85 \\
0.98\end{array}$ & 3.0 \\
\hline $\begin{array}{l}\text { Ventricular } \\
\text { fuid }\end{array}$ & $\begin{array}{l}\text { PP } \\
\text { Average } \\
2 \text { exper. }\end{array}$ & $\begin{array}{l}1 \mathrm{hr} . \\
3 \mathrm{hr} .\end{array}$ & $\begin{array}{l}0.10 \\
0.20\end{array}$ & $\begin{array}{l}0.26 \\
0.46\end{array}$ & $\begin{array}{l}0.38 \\
0.43\end{array}$ & 5.0 \\
\hline
\end{tabular}

per cent. Observations with radioactive iodine, using "tracer" amounts, indicate remarkably high gastric juice : blood ratios (22). Finally, although there is agreement that there is proportionately less bromide in the spinal fluid than chloride, there is not always agreement regarding the degree of this dissimilarity in the distribution of these ions $(23,24)$.

With reference to the differences between the volumes of distribution of chloride and of sodium, Harrison, Darrow, and Yannet (25) described significant amounts of "excess" of sodium over chloride in animals and considered most of this sodium to be located in the bone. This observation has been supported by workers using radioactive sodium $(26,27)$, and the increment of the sodium space between 1 and 24 hours is assumed to be for the most part a measure of the distribution of sodium in bone. The distribution of sodium and chloride in the other tissues has been studied with chemical methods $(28,29)$ and with isotope techniques $(30,31)$.

In attempting to evaluate the difference between the $\mathrm{Cl}^{38}$ space and the sucrose space and to clarify the relations of each to the extracellular fluid, it is necessary to consider first, the distribution of these materials under ideal conditions that would allow equilibrium to become complete, and second, the limitations of our presently available methods in describing this state. Chloride is known to enter certain cells, particularly the cells of the blood, renal tubules, gastric mucosa, skin and lungs (28, 29); and hence the space it measures is larger than the extracellular fluid volume. Exact data, however, are not available to calculate that portion of the total body chloride that is inside the cells. Although direct studies of the tissue distribution of sucrose have not been reported, it is known that sucrose does not enter red cells (32); and because it can be quantitatively recovered from the urine and hence is not metabolized, it is believed to maintain an extracellular position $(6,32)$. Sucrose does not enter the cerebrospinal fluid (33) or the gastrointestinal juices, and hence the space does not include these compartments that are included in the spaces measured by the electrolytes. Turning to the limitations of the methods, as mentioned previously the time during which the spaces of $\mathrm{Cl}^{38}$ and sucrose can be determined is limited. From dilution data using $\mathrm{Cl}^{36}$ (2) and bromide 
(4, and Table I) it appears that by 2.5 hours the volume of distribution of the injected chloride has probably expanded to at least 95 per cent of its maximal value. Deane has reported that maximal values of sucrose are reached in less than three hours (6). Evidence, however, that complete equilibrium may not be attained by three hours has been presented by Cotlove (34) who has demonstrated increasing amounts of sucrose in rat muscle as constant infusions were maintained for 2,6 , and 15 hours. The sucrose space measurements in Table II show small increases between two and one-fourth and three and three-fourths hours. These considerations of the incompleteness of our knowledge of the distribution of sucrose and of chloride and of the limitations of the available dilution methods discourage quantitative statements relating the extracellular fluid to the volume of distribution of either $\mathrm{Cl}^{38}$ or sucrose.

\section{SUM MARY}

The volumes of distribution of $\mathrm{Cl}^{38}, \mathrm{Na}^{24}$, stable bromide, and sucrose were determined simultaneously in five patients. The volumes of distribution of $\mathrm{Cl}^{38}$ and $\mathrm{Br}^{82}$ were determined simultaneously in 10 patients.

Using average values obtained two and one-half hours after injection and setting the volume of distribution of chloride at unity, the relative values obtained with the other agents were 1.07 for sodium, 1.07 for stable bromide, 1.02 for radioactive bromide, and 0.77 for sucrose.

\section{ACKNOWLEDGMENTS}

The ventricular fluid samples were obtained by Dr. Herbert Locksley of the Massachusetts General Hospital.

The authors wish to acknowledge the technical assistance of Mrs. Nancy Lee and Miss Mary Kinsley.

\section{REFERENCES}

1. Moore, F. D., Determination of total body water and solids with isotopes. Science, 1946, 104, 157.

2. Ray, C. T., Burch, G. E., Threefoot, S. A., Biologic decay rates of chloride in normal and diseased man, determined with long-life radiochlorine, Cl-36. J. Lab. \& Clin. Med., 1952, 39, 673.

3. Forbes, G. B., Perley, A., Estimation of total body sodium by isotopic dilution. I. Studies on young adults. J. Clin. Invest., 1951, 30, 558.

4. Brodie, B. B., Brand, B., Leshin, S., The use of bromide as a measure of extracellular fluid. J. Biol. Chem., 1939, 130, 555.
5. Dunning, M. F., Steele, J. M., and Berger, E. Y. Measurement of total body chloride. Proc. Soc. Exper. Biol. \& Med., 1951, 77, 854.

6. Deane, N., Schreiner, G. E., and Robertson, J. S., The velocity of distribution of sucrose between plasma and interstitial fluid, with reference to the use of sucrose for the measurement of extracellular fluid in man. J. Clin. Invest., 1951, 30, 1463.

7. Deane, N., and Smith, H. W., The distribution of sodium and potassium in man. J. Clin. Invest., 1952, 31, 197.

8. Deane, N., Ziff, M., and Smith, H. W., The distribution of total body chloride in man. J. Clin. Invest., 1952, 31, 200.

9. Gamble, J. L., Jr., and Robertson, J. S., Volume of distribution of radioactive chloride in dogs ; comparisons with sodium, bromide and inulin spaces. Am. J. Physiol., 1952, 171, 659.

10. Schreiner, G. E., Determination of inulin by means of resorcinol. Proc. Soc. Exper. Biol. \& Med., 1950, 74, 117.

11. Brodie, B. B., and Friedman, M. M., The determination of bromide in tissues and in biological fluids. J. Biol. Chem., 1938, 124, 511.

12. Van Slyke, D. C., and Hiller, A., Application of Sendroy's iodometric chloride titration to protein-containing fluids. J. Biol. Chem., 1947, 167, 107.

13. Van Slyke, D. D., Hiller, A., Phillips, R. A., Hamilton, P. B., Dole, V. P., Archibald, R. M., and Eder, H. A., The estimation of plasma protein concentration from plasma specific gravity. J. Biol. Chem., $1950,183,331$.

14. Weir, E. G., and Hastings, A. B., The distribution of bromide and chloride in tissues and body fluids. J. Biol. Chem., 1939, 129, 547.

15. Wallace, G. B., and Brodie, B. B., The distribution of administered bromide in comparison with chloride and its relation to body fluids. J. Pharmacol. \& Exper. Therap., 1939, 65, 214.

16. Wolf, R. L., and Eadie, G. S., Reabsorption of bromide by the kidney. Am. J. Physiol., 1950, 163, 436.

17. Mason, M. F., Halide distribution in body fluids in chronic bromide intoxication. J. Biol. Chem., 1936, 113, 61.

18. Hastings, A. B., and Van Dyke, H. B., Studies of bromide distribution in the blood. I. In vitro experiments of bromide and chloride distributions. J. Biol. Chem., 1931, 92, 13.

19. Smith, P. K., Eisenman, A. J., and Winkler, A. W., The permeability of human erythrocytes to radioactive chloride, and to bromide and iodide. J. Biol. Chem., 1941, 141, 555.

20. Davenport, H. W., and Fisher, R. B., The meehanism of the secretion of acid by the gastric mucosa. Am. J. Physiol., 1940, 131, 165.

21. Davenport, H. W., The secretion of iodide by the gastric mucosa. Gastroenterology, 1943, 1, 1055. 
22. Johnson, H. W., and Albert, A., The excretion and distribution of I-131 following administration of physiologic amounts of labeled iodide, diiodotyrosine and thyroxine in the rat. Endocrinology, 1951, 48, 669.

23. Zetterholm, S., Blood-spinal fluid permeability to bromide in closed head injuries. Acta psychiat. et neurol., 1947, supp. 45, 1.

24. Patrick, S. I., and Eadie, G. S., Bromides in spinal fluid and serum. Am. J. Physiol., 1952, 168, 254.

25. Harrison, H. E., Darrow, D. C., and Yannet, H., The total electrolyte content of animals and its probable relation to the distribution of body water. J. Biol. Chem., 1936, 113, 515.

26. Kaltreider, N. L., Meneely, G. R., Allen, J. R., and Bale, W. F., Determination of the volume of the extracellular fluid of the body with radioactive sodium. J. Exper. Med., 1941, 74, 569.

27. Edelman, I. S., James, A. H., and Moore, F. D., Penetration of sodium and water into bone as measured with radiosodium and $\mathrm{D}_{2} \mathrm{O}$. Federation Proc., 1952, 11, 40.
28. Manery, J. F., and Hastings, A. B., The distribution of electrolytes in mammalian tissues. J. Biol. Chem., 1939, 127, 657.

29. Amberson, W. R., Nash, T. P., Mulder, A. G., and Binns, $D$., The relationship between tissue chloride and plasma chloride. Am. J. Physiol., 1939, 122, 224.

30. Manery, J. F., and Bale, W. F., The penetration of radioactive sodium and phosphorus into the extraand intracellular phases of tissues. Am. J. Physiol., 1941, 132, 215.

31. Manery, J. F., and Haege, L. F., The extent to which radioactive chloride penetrates tissues, and its significance. Am. J. Physiol., 1941, 134, 83.

32. Keith, N. M., and Power, M. H., The urinary excretion of sucrose and its distribution in the blood after intravenous injection into normal men. Am. J. Physiol., 1937, 120, 203.

33. Hubbard, R. S., and Zoll, J., Entrance of intravenously injected sucrose into the cerebrospinal fluid. Proc. Soc. Exper. Biol. \& Med., 1949, 70, 394.

34. Cotlove, E., Inulin and chloride space in muscle. Federation Proc., 1952, 11, 28. 